\title{
Morphological characterization and analysis of genetic variability among pepper accessions
}

\author{
Caracterização morfológica e análise da variabilidade \\ genética entre acessos de pimenta
}

\author{
Paola Alvares Bianchi ${ }^{\mathrm{I}}$ Iris Petronilia Dutra ${ }^{\mathrm{I}}$ Monique Moreira Moulin ${ }^{\mathrm{I}^{*}}$ \\ Jardel Oliveira Santos ${ }^{\text {II }}$ Alexandre Cristiano Santos Júnior ${ }^{\mathrm{I}}$
}

\section{ABSTRACT}

The peppers of the genus Capsicum have economic potential and elevated genetic variability. The objective of the study was to characterize morpho-agronomically and estimate the genetic divergence among pepper accessions of the active germplasm bank of Capsicum of the Instituto Federal do Espirito Santo, Campus Alegre. Thirty accessions were characterized based on ten morphological descriptors being the experimental design completely randomized, with six repetitions. Genetic diversity among the accessions was estimated by the Tocher grouping method as a measurement of dissimilarity and formed eight groups. The Singh method, used to estimate the relative contribution of each character in the expression of genetic divergence, indicated that the diameter of the produce $(20.19 \%)$ and the height of the plant $(19.46 \%)$ were the ones to contribute most to the total divergence (39.65\%) among the accessions of pepper being studied. The study evidenced the existence of high genetic variability among the accessions of $\boldsymbol{C}$. annum collected in the south region of the state of Espirito Santo. No correlation was detected between the genetic distance and location of collections.

Key words: Capsicum, phenotypic divergence, genetic resources, germplasm characterization.

\section{RESUMO}

As pimentas do gênero Capsicum possuem potencial econômico e elevada variabilidade genética. Objetivou-se realizar a caracterização morfoagronômica e estimar a divergência genética entre acessos de pimenta do banco ativo de germoplasma de Capsicum do Instituto Federal do Espírito Santo, Campus de Alegre. Foram caracterizados trinta acessos com base em dez descritores morfológicos, sendo o delineamento experimental inteiramente casualizado, com seis repetições. A divergência genética entre os acessos foi estimada pelo método de agrupamento de Tocher, como medida de dissimilaridade, formando-se oito grupos. O método de Singh, utilizado para estimar a contribuição relativa de cada caráter na expressão da divergência genética, indicou que o diametro do fruto (20,19\%) e a altura da planta $(19,46 \%)$ foram os que mais contribuíram para a divergência total (39,65\%) entre os acessos de pimenta avaliados. O estudo realizado evidencia a existência de alta variabilidade genética entre os acessos de C. annuum coletados no Sul do Estado do Espírito Santo. Não foi detectada correlação entre a distância genética e os locais de coleta.

Palavras-chave: Capsicum, divergência fenotipica, recursos genéticos, caracterização de germoplasma.

\section{INTRODUCTION}

The genus Capsicum includes the peppers and chilies, has a great nutritional and economic value, and is widely grown in the whole world (HILL et al., 2013). Brazil is a diversity center for the genus, housing domesticated, semi-domesticated and wild species (MOSCONE et al., 2007).

The species of the Capsicum genus have great variability in its main morphological characters, such as form, size, color and position of flowers and fruits. Pepper plants are preferably autogamous, diploid with $2 n=2 x=24$ or $2 n=2 x=26$ chromosomes and have pungency as a marking characteristic, which is attributed to the alkaloid substances, more specifically the capsaicinoids (MOSCONE et al., 2007).

Pepper fruits are present in the cuisine of most countries and the wide diversity of the genus results in multiple uses, as dry fruits for consumption

\footnotetext{
Instituto Federal do Espírito Santo (IFES), 29500-000, Alegre, ES, Brasil. E-mail: mmmoulin@ifes.edu.br. "Corresponding author.

IUniversidade Federal do Maranhão (UFMA), Chapadinha, MA, Brasil.
} 
in natura, or dried for the processing in powder or extracts (ALBRECHT et al., 2012). Growth of pepper is important both for profitability, mainly when the producer adds value to the product and for its social importance in high labor employment (RÊGO et al., 2011). Knowledge of the genetic diversity present among the accessions has great importance for the management and use of the germplasm in the genetic improvement of species. Variability presented by the individuals constitutes the genetic resources, whose characterization and evaluation are essential for plant breeding projects (SUDRÉ et al., 2005). According to NEITZKE et al. (2010) the increase of these activities must be a priority among the strategies of approach to and management of the genetic resources in Brazil.

For the peppers there is little availability of scientific information on its morphology and other characters that give quality to produce, evidencing the lack of improved varieties. Many species of the Capsicum genus, are still poorly worked, from genetic improvement point of view (RODRIGUES et al., 2012).

GONÇALVES etal.(2008) decribed that the characterization can be morphological, phenotipical reproductive, biochemical, cytogenetic or molecular. In this context,studies with morphological markers make significant contributions to the understanding of the genetic diversity. There is a need to study the agrobiodiversity and best use of the genotype's potential, so this research had the objective of characterizing, by means of morphological descriptors, 30 accessions of the active germplasm bank of Capsicum of the Instituto Federal do Espírito Santo, Campus de Alegre.

\section{MATERIALS AND METHODS}

The fruits of pepper were collected in rural properties, markets and fairs located in the south regions of the Espírito Santo State, in the municipalities of Alegre, Cachoeiro de Itapemirim and Venda Nova do Imigrante, totaling 30 accessions. Seeds of the collected fruit were planted in $5 \mathrm{~L}$ pots and later, after 90 days of plantation, the morphological characterization of the accessions was carried out. The plants were conducted under field conditions following the recommendations of FILGUEIRA (2008) for pepper culture.

Accessions were characterized by the following morpho-agronomical descriptors: form of fruits (FRF), plant height (PH), diameter of the cup (DC), fruit length (FRL), fruit diameter (FRD), number of seeds per fruit (NS), number of locules per fruit (NL), stem width (SW), leaf width (LW) and leaf length (LL).

For the morphological characterization, six repetitions of each accession were used; totaling 180 plants grown in the nursery of the Instituto Federal do Espírito Santo, Campus Alegre. The experimental design for the analysis of the variances of each character was completely randomized. For the comparison among the averages of the accessions the SCOTT-KNOTT (1974) grouping criteria at $1 \%$ probability was used.

In the multivariate analysis, the genetic divergence among the accessions was determined by the Tocher (RAO, 1952) method. The identification of the importance of the characters was done based on the Singh (SINGH, 1981) method.

The statistical-genetic analyses were carried out with the aid of the Genes program (CRUZ, 2008). Grouping of accessions was obtained by the Unweighted Paired Group Method using Arithmetic averages (UPGMA) method.

\section{RESULTS AND DISCUSSION}

A great phenotypic variability for the ten characters studied was evidenced. Taking into account the format standards (Table 1) and the morphological characteristics assessed (number of seeds, stem width, fruit length, fruit diameter, number of locules, height of the plant, diameter of the cup, width of the leaf and length of the leaf) it was observed that the pepper accessions present great variation. Measurements that presented significant differences among them were obtained in all the characters (Table 2), being these grouped by the Scott e Knott test (SCOTT \& KNOTT, 1974) at a level of significance of $1 \%$ probability. Other studies on the variability and genetic parameters in Capsicum, using morphological markers are described in the literature (BENTO et al., 2007; FINGER et al., 2010; NEITZKE et al., 2010; RÊGO et al., 2011; DOMENICO et al., 2012; SILVA NETO et al., 2014).

Greater number of classes was observed for the plant height characteristic, totaling eight, followed by the diameter of the fruit character for which seven classes were reported (Table 2). The number of classes evidenced a good genetic variety for those characteristics. For the number of seeds, leaf diameter, and leaf length characters, a smaller number of classes were observed, only three for each characteristic. Studies carried out by SUDRÉ et al. (2005) confirmed that the characteristics with greater 
Table 1 - List of 30 pepper accessions originating from the active germplasm bank of the Instituto Federal do Espírito Santo, Campus Alegre, including the place of origin and the fruit form.

\begin{tabular}{|c|c|c|}
\hline Number of accession & Origin & Form of the fruit \\
\hline IFES 01 & Rural property in Alegre & Elongated \\
\hline IFES 02 & Rural property in Alegre & Elongated \\
\hline IFES 03 & Rural property in Alegre & Elongated \\
\hline IFES 04 & Rural property in Alegre & Round \\
\hline IFES 05 & Rural property in Alegre & Square \\
\hline IFES 06 & Rural property in Alegre & Triangular \\
\hline IFES 07 & Rural property in Alegre & Elongated \\
\hline IFES 08 & Rural property in Alegre & Round \\
\hline IFES 09 & Rural property in Alegre & Elongated \\
\hline IFES 10 & Rural property in Alegre & Elongated \\
\hline IFES 11 & Rural property in Venda Nova do Imigrante & Triangular \\
\hline IFES 12 & Rural property in Venda Nova do Imigrante & Elongated \\
\hline IFES 13 & Rural property in Venda Nova do Imigrante & Elongated \\
\hline IFES 14 & Rural property in Venda Nova do Imigrante & Round \\
\hline IFES 15 & Business establishment de Cachoeiro de Itapemirim & Campanulate \\
\hline IFES 16 & Business establishment in Cachoeiro de Itapemirim & Triangular \\
\hline IFES 17 & Business establishment in Cachoeiro de Itapemirim & Triangular \\
\hline IFES 18 & Business establishment in Cachoeiro de Itapemirim & Elongated \\
\hline IFES 19 & Business establishment in Cachoeiro de Itapemirim & Elongated \\
\hline IFES 20 & Business establishment in Alegre & Triangular \\
\hline IFES 21 & Business establishment in Alegre & Round \\
\hline IFES 22 & Business establishment in Venda Nova do Imigrante & Round \\
\hline IFES 23 & Business establishment in Venda Nova do Imigrante & Square \\
\hline IFES 24 & Business establishment in Venda Nova do Imigrante & Campanulate \\
\hline IFES 25 & Business establishment in Venda Nova do Imigrante & Elongated \\
\hline IFES 26 & Rural property in Venda Nova do Imigrante & Elongated \\
\hline IFES 27 & Rural property in Venda Nova do Imigrante & Triangular \\
\hline IFES 28 & Rural property in Venda Nova do Imigrante & Triangular \\
\hline IFES 29 & Rural property in Venda Nova do Imigrante & Elongated \\
\hline IFES 30 & Rural property in Venda Nova do Imigrante & Square \\
\hline
\end{tabular}

number of classes were: length and diameter of the fruit. Diverging results were obtained by NEITZKE et al. (2010) who described a greater number of classes for the length of the fruit character and smaller for plant height. SILVA NETO et al. (2014) confirmed that the characteristics that present greater variability were diameter of the stem and diameter of the cup with thirteen and eight groups respectively.

As for the variation coefficient (CV) a maximum value of 44,25 was obtained for the number of seeds character and a minimum value of 11,22 for diameter of the stem, being these considered rather satisfactory for the descriptors used. Results obtained in this for the $\mathrm{CV}$ were more favorable than those obtained in other studies with pepper (BENTO et al., 2007; NEITZKE et al., 2010; DOMENICO et al., 2012), which evidences a great genetic variability of the genotypes studied.
For the number of seeds (NS), the maximum and minimum of the averages were 51 seeds for the IFES 6 accession and six for the IFES 21 accession respectively, being the general average 25.02 (Table 2). RÊGO et al. (2011) obtained higher average values for the number of seeds per fruit, varying between 8 and 144 seeds; however, authors characterized accessions previously selected in higher numbers than those of this study totaling 69 which may explain said higher variation obtained.

The characteristic width of the stem (SW) had a maximum average of $0.76 \mathrm{~mm}$ for the IFES 27 accession and a minimum of $0.36 \mathrm{~mm}$ the IFES 11 , with a general average of $0.62 \mathrm{~mm}$. SILVANETO et al. (2014) observed similar values when characterizing C. annuum plants of ornamental potential of a $F_{2}$ generation. According to the same authors, thicker stems are of interest to the improvement since plants 
Table 2 - Averages ${ }^{1}$ of the 30 accessions of pepper with respect to nine morphological characters.

\begin{tabular}{|c|c|c|c|c|c|c|c|c|c|}
\hline Genotype & NS (un) & WS (mm) & $\mathrm{LFR}(\mathrm{cm})$ & $\operatorname{DFR}(\mathrm{cm})$ & NL (un) & $\mathrm{HP}(\mathrm{cm})$ & $\mathrm{DC}(\mathrm{cm})$ & $\mathrm{WL}(\mathrm{cm})$ & $\mathrm{LL}(\mathrm{cm})$ \\
\hline IFES 1 & $15.5 \mathrm{c}$ & $5.94 b$ & $2.15 \mathrm{e}$ & $0.58 \mathrm{~g}$ & $2.00 \mathrm{~d}$ & $35.00 \mathrm{~g}$ & $43.66 \mathrm{e}$ & $3.95 \mathrm{~b}$ & $8.76 \mathrm{a}$ \\
\hline IFES 2 & $20.5 \mathrm{c}$ & $6.09 \mathrm{~b}$ & $1.96 \mathrm{e}$ & $2.30 \mathrm{c}$ & $3.66 \mathrm{a}$ & $37.16 \mathrm{~g}$ & $83.00 \mathrm{a}$ & $2.23 \mathrm{c}$ & $3.71 \mathrm{c}$ \\
\hline IFES 3 & $21.1 \mathrm{c}$ & $7.23 \mathrm{a}$ & $1.31 \mathrm{f}$ & $1.21 \mathrm{e}$ & $2.00 \mathrm{~d}$ & $44.00 \mathrm{f}$ & $53.33 \mathrm{~d}$ & $3.71 \mathrm{c}$ & $7.03 \mathrm{~b}$ \\
\hline IFES 4 & $18.33 \mathrm{c}$ & $6.10 \mathrm{~b}$ & $0.71 \mathrm{f}$ & $1.41 \mathrm{e}$ & $3.33 b$ & $43.16 f$ & $53.33 \mathrm{~d}$ & $3.45 \mathrm{c}$ & $3.00 \mathrm{c}$ \\
\hline IFES 5 & $28.16 b$ & $4.95 \mathrm{c}$ & $2.48 \mathrm{~d}$ & $1.50 \mathrm{e}$ & $2.16 \mathrm{~d}$ & $60.83 d$ & $47.83 d$ & $2.55 \mathrm{c}$ & $4.46 c$ \\
\hline IFES 6 & $51.00 \mathrm{a}$ & $6.34 b$ & $2.63 \mathrm{~d}$ & $3.28 \mathrm{~b}$ & $3.50 \mathrm{~b}$ & $58.50 \mathrm{~d}$ & $71.83 b$ & $3.31 \mathrm{c}$ & $5.53 \mathrm{c}$ \\
\hline IFES 7 & $23.33 \mathrm{c}$ & $3.78 \mathrm{~d}$ & $1.91 \mathrm{e}$ & $1.86 \mathrm{e}$ & $4.00 \mathrm{a}$ & $24.00 \mathrm{~h}$ & $49.66 \mathrm{~d}$ & $2.81 \mathrm{c}$ & $5.25 \mathrm{c}$ \\
\hline IFES 8 & $48.00 \mathrm{a}$ & $6.21 \mathrm{~b}$ & $2.95 \mathrm{c}$ & $3.75 \mathrm{a}$ & $4.00 \mathrm{a}$ & $52.50 \mathrm{e}$ & $44.83 \mathrm{e}$ & $4.71 b$ & $8.83 a$ \\
\hline IFES 9 & $19.00 \mathrm{c}$ & $7.24 \mathrm{a}$ & $1.88 \mathrm{e}$ & $2.46 \mathrm{c}$ & $3.50 \mathrm{~b}$ & $50.16 \mathrm{e}$ & $54.66 \mathrm{~d}$ & $4.76 \mathrm{~b}$ & $7.03 b$ \\
\hline IFES 10 & $12.50 \mathrm{c}$ & $5.51 \mathrm{~b}$ & $3.80 \mathrm{~b}$ & $3.05 \mathrm{~b}$ & $4.00 \mathrm{a}$ & $44.00 \mathrm{f}$ & $53.16 \mathrm{~d}$ & $4.16 \mathrm{~b}$ & $7.30 \mathrm{~b}$ \\
\hline IFES 11 & $12.16 \mathrm{c}$ & $3.56 \mathrm{~d}$ & $1.15 \mathrm{f}$ & $1.51 \mathrm{e}$ & $2.33 \mathrm{c}$ & $18.00 \mathrm{~h}$ & $33.66 \mathrm{e}$ & $3.21 \mathrm{c}$ & $4.61 \mathrm{c}$ \\
\hline IFES 12 & $28.00 \mathrm{~b}$ & $6.38 b$ & $2.25 \mathrm{~d}$ & $2.10 \mathrm{~d}$ & $3.16 \mathrm{~b}$ & $52.66 \mathrm{e}$ & $67.00 \mathrm{c}$ & $2.56 \mathrm{c}$ & $4.18 \mathrm{c}$ \\
\hline IFES 13 & $31.83 b$ & $6.60 \mathrm{~b}$ & $5.50 \mathrm{a}$ & $1.06 \mathrm{f}$ & $2.16 \mathrm{~d}$ & $68.50 \mathrm{c}$ & $76.83 b$ & $3.15 \mathrm{c}$ & $5.91 \mathrm{c}$ \\
\hline IFES 14 & $11.33 \mathrm{c}$ & $7.24 \mathrm{a}$ & $1.78 \mathrm{e}$ & $0.71 \mathrm{~g}$ & $2.00 \mathrm{~d}$ & $52.50 \mathrm{e}$ & $65.00 \mathrm{c}$ & $3.11 \mathrm{c}$ & $5.36 \mathrm{c}$ \\
\hline IFES 15 & $16.33 \mathrm{c}$ & $6.33 b$ & $1.83 \mathrm{e}$ & $0.61 \mathrm{~g}$ & $2.00 \mathrm{~d}$ & $49.50 \mathrm{e}$ & $53.33 d$ & $2.48 \mathrm{c}$ & $5.51 \mathrm{c}$ \\
\hline IFES 16 & $42.66 \mathrm{a}$ & $6.10 \mathrm{~b}$ & $3.73 b$ & $1.38 \mathrm{e}$ & $2.83 \mathrm{~b}$ & $73.50 \mathrm{c}$ & $91.5 \mathrm{a}$ & $4.01 \mathrm{~b}$ & $6.75 b$ \\
\hline IFES 17 & $20.83 c$ & $6.55 b$ & $4.06 \mathrm{~b}$ & $0.98 \mathrm{f}$ & $2.00 \mathrm{~d}$ & $70.33 c$ & $92.33 \mathrm{a}$ & $3.05 \mathrm{c}$ & $5.63 \mathrm{c}$ \\
\hline IFES 18 & $12.00 \mathrm{c}$ & $6.70 \mathrm{a}$ & $1.63 \mathrm{e}$ & $0.58 \mathrm{~g}$ & $2.00 \mathrm{~d}$ & $51.00 \mathrm{e}$ & $43.66 \mathrm{e}$ & $3.53 \mathrm{c}$ & $7.78 b$ \\
\hline IFES 19 & $22.50 \mathrm{c}$ & $6.12 b$ & $1.70 \mathrm{e}$ & $1.18 \mathrm{e}$ & $2.33 \mathrm{c}$ & $56.83 \mathrm{~d}$ & $73.66 \mathrm{~b}$ & $2.85 \mathrm{c}$ & $4.80 \mathrm{c}$ \\
\hline IFES 20 & $19.83 c$ & $6.07 \mathrm{~b}$ & $1.86 \mathrm{e}$ & $1.70 \mathrm{e}$ & $2.00 \mathrm{~d}$ & $62.66 \mathrm{~d}$ & $65.83 \mathrm{c}$ & $4.35 b$ & $4.98 \mathrm{c}$ \\
\hline IFES 21 & $6.00 \mathrm{c}$ & $7.16 \mathrm{a}$ & $1.00 \mathrm{f}$ & $0.30 \mathrm{~g}$ & $2.00 \mathrm{~d}$ & $57.50 \mathrm{~d}$ & $45.50 \mathrm{e}$ & $3.60 \mathrm{c}$ & $6.56 \mathrm{~b}$ \\
\hline IFES 22 & $27.83 b$ & $6.49 \mathrm{~b}$ & $2.51 \mathrm{~d}$ & $1.45 \mathrm{e}$ & $2.16 \mathrm{~d}$ & $50.33 \mathrm{e}$ & $76.66 \mathrm{~b}$ & $4.06 \mathrm{~b}$ & $6.65 b$ \\
\hline IFES 23 & $32.5 b$ & $5.32 \mathrm{c}$ & $3.80 \mathrm{~b}$ & $1.00 \mathrm{f}$ & $2.66 \mathrm{c}$ & $88.50 \mathrm{a}$ & $91.33 \mathrm{a}$ & $3.90 \mathrm{~b}$ & $6.85 b$ \\
\hline IFES 24 & $20.16 c$ & $7.06 \mathrm{a}$ & $1.06 \mathrm{f}$ & $1.36 \mathrm{e}$ & $3.00 \mathrm{~b}$ & $77.66 \mathrm{~b}$ & $88.50 \mathrm{a}$ & $6.01 \mathrm{a}$ & $9.48 \mathrm{~b}$ \\
\hline IFES 25 & $11.16 \mathrm{c}$ & $6.80 \mathrm{a}$ & $1.75 \mathrm{e}$ & $0.46 \mathrm{~g}$ & $2.16 \mathrm{~d}$ & $79.00 \mathrm{~b}$ & $83.33 \mathrm{a}$ & $4.40 \mathrm{~b}$ & $8.36 \mathrm{a}$ \\
\hline IFES 26 & $31.5 b$ & $6.66 b$ & $1.91 \mathrm{e}$ & $1.26 \mathrm{e}$ & $2.66 \mathrm{c}$ & $50.33 \mathrm{e}$ & $71.16 b$ & $4.06 \mathrm{~b}$ & $6.83 b$ \\
\hline IFES 27 & $45.33 \mathrm{a}$ & $7.64 \mathrm{a}$ & $2.70 \mathrm{~d}$ & $2.43 \mathrm{c}$ & $3.00 \mathrm{~d}$ & $57.16 \mathrm{~d}$ & $66.66 \mathrm{c}$ & $6.71 \mathrm{a}$ & $10.26 \mathrm{a}$ \\
\hline IFES 28 & $28.50 \mathrm{~b}$ & $6.78 \mathrm{a}$ & $2.03 \mathrm{e}$ & $1.95 \mathrm{~d}$ & $2.50 \mathrm{~d}$ & $59.00 \mathrm{~d}$ & $85.50 \mathrm{a}$ & $2.90 \mathrm{c}$ & $4.65 c$ \\
\hline IFES 29 & $41.00 \mathrm{a}$ & $3.83 \mathrm{~d}$ & $2.65 \mathrm{~d}$ & $1.78 \mathrm{e}$ & $3.16 \mathrm{~b}$ & $43.16 f$ & $41.00 \mathrm{e}$ & $4.18 b$ & $6.50 \mathrm{~b}$ \\
\hline IFES 30 & $31.66 \mathrm{~b}$ & $7.48 \mathrm{a}$ & $3.56 \mathrm{~b}$ & $2.75 \mathrm{c}$ & $3.33 b$ & $61.33 \mathrm{~d}$ & $77.66 \mathrm{~b}$ & $4.20 \mathrm{~b}$ & $7.90 \mathrm{~b}$ \\
\hline Averages & 25.02 & 6.21 & 2.34 & 1.60 & 2.72 & 54.29 & 64.84 & 3.73 & 6.45 \\
\hline $\mathrm{CV} \%$ & 44.25 & 11.22 & 25.55 & 25.32 & 15.13 & 12.37 & 13.75 & 35.52 & 32.38 \\
\hline
\end{tabular}

${ }^{1}$ Averages followed by the same letter, in each column, belong to a same class, in accordance with the Scott-Knott test $(\mathrm{P}<0.01)$. NS $=$ number of seeds; WS = width of the stem; LFR = length of the fruit; DFR = diameter of the fruit; $\mathrm{NL}=$ number of locules; $\mathrm{HP}=$ height of the plant; $\mathrm{DC}=$ diameter of the cup; $\mathrm{WL}=$ width of the leaf; $\mathrm{LL}=$ length of the leaf.

with very thin stems tend to bed and lose their commercial value.

With respect to the length of the fruit (FRL), an average of $2.34 \mathrm{~cm}$ was obtained with a maximum value of $5.5 \mathrm{~cm}$ for the IFES 13 accession and a minimum of 0.71 for the IFES 4 accession. JARRET \& BERKE (2008) observed a variation of $0.8 \mathrm{~cm}$ to $11.4 \mathrm{~cm}$. DOMENICO et al. (2012) reported values of $2.1 \mathrm{~cm}$ to $7.7 \mathrm{~cm}$. For the diameter of the fruit (FRD) a greater variability was detected, having seven classes been identified, with a maximum average of $3.75 \mathrm{~cm}$ for the IFES 8 accession, and minimum of $0.3 \mathrm{~cm}$ for the IFES
21 and general average for the character of $1.60 \mathrm{~cm}$. FONSECA et al. (2008) obtained averages that vary between $0.7 \mathrm{~cm}$ and $2.5 \mathrm{~cm}$, while, DOMENICO et al. (2012) observed a smaller variation of $1.1 \mathrm{~cm}$ to $2.5 \mathrm{~cm}$ for this characteristic.

With respect to the variable number of locules (NL) a general average of 2.72 was confirmed and as expected there was low variability for this character, the fruits had between two and four locules, obtaining a maximum average of four locules for the IFES 7, IFES 8 and IFES 10 accessions. Similarly, REGGO et al. (2011) when characterizing 69 accessions of Capsicum reported a variation between two and four locules. 
In the determination of the plant height $(\mathrm{PH})$, it was observed that the maximum and minimum values were between $18.00 \mathrm{~cm}$ and $88.50 \mathrm{~cm}$, with an average of $54.29 \mathrm{~cm}$. The IFES 23 accession presented the highest average and the IFES 11 accession the lowest. NEITZKE et al. (2010) obtained values similar to those observed in this research, varying between $15.03 \mathrm{~cm}$ and $78.40 \mathrm{~cm}$ in plant height. The diameter of the cup (DC) presented a general average of $64.84 \mathrm{~cm}$, with the lowest average for the IFES 11 accession $(33.66 \mathrm{~cm})$ and the for the highest IFES 17 accession $(92.33 \mathrm{~cm})$. In the management of germplasm banks, especially in the regeneration and multiplication of the accessions stages, this character aids in the choosing of more adequate spacing with respect to the diameter of the cup of each accession (BENTO et al., 2007).

For the foliar characteristics, width (LW) and length (LL), averages of $3.73 \mathrm{~cm}$ and $6.45 \mathrm{~cm}$ respectively were detected. The width varied between $2.23 \mathrm{~cm}$ and $6.71 \mathrm{~cm}$ and the length between $3.00 \mathrm{~cm}$ and $10.26 \mathrm{~cm}$. The IFES 27 accession presented the greatest width and length, while the IFES 2 accession presented the lower averages for both plant characteristics. SILVA NETO et al. (2014) detected a variation of $1.36 \mathrm{~cm}$ to $2.33 \mathrm{~cm}$ for the width of the leaf, and of $2.9 \mathrm{~cm}$ to $5.27 \mathrm{~cm}$ for the length of the leaf. In the classification of the fruits with respect to shape (FRF), the predominant shape was the Elongated $(43,33 \%)$, in addition to the occurrence of other shapes of lower proportions, triangular (23.34\%), round $(16.66 \%)$, square $(10.00 \%)$ and campanulate $(6.67 \%)$. In agreement with the results obtained, JARRET \& BERKE (2008), when evaluating the accessions of $\boldsymbol{C}$. annuum also reported predominance of the Elongated shape.

Most distant genotypes are the IFES 11 and IFES 23 accessions, with a distance of 162.48, while the IFES 22 and IFES 26 accessions were considered the closest with a distance of 3.60. The grouping of the genotypes by means of the Tocher method resulted in the formation of eight groups (Figure 1). Group I holds eleven accessions, being that the largest group

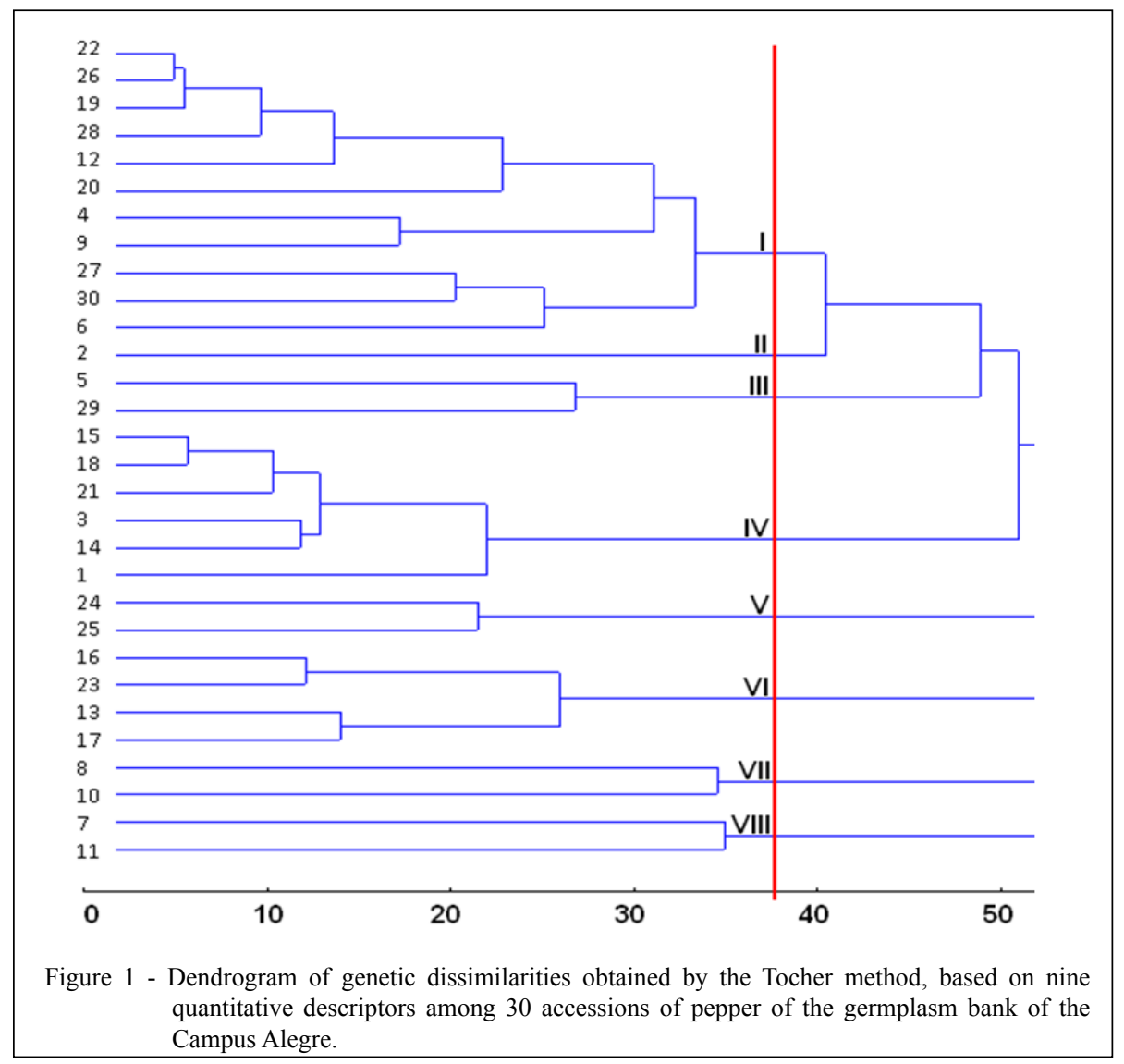

Ciência Rural, v.46, n.7, jul, 2016. 
(characterized for having a high number of seeds, diameter of the stem and diameter of the cup). Group II, formed by one accession, IFES 2 (was differentiated for having a smaller foliar width and length). Group III was formed by two accessions (characterized by low caliber stems, average length and diameter of the fruit and average diameter of the cup). Group IV was represented by six accessions (lower number of seeds, low values for length and diameter of the fruit and two locules were observed). In this group were placed the accessions with ornamental characteristics, small fruit with different colors.

In group $\mathrm{V}$ two accessions were placed (that have small dark red fruit with leaves large in length as common characteristics). Group VI, composed by four accessions (largest fruit lengths and high average height of the pepper plants). Groups VII and VIII, composed of two accessions each, grouped the fruits of greater diameter in one and plants with lower average height in the other.

In this investigation it was not possible to confirm the correlation between genetic diversity, based on the study of morphological attributes, and place of origin of the accessions given that in the same group were arranged genotypes collected in rural properties and markets of different municipalities, Alegre, Cachoeiro de Itapemirim and Venda Nova do Imigrante, in the Espírito Santo state. In agreement with this study, other studies with different oleraceous plants also described not having correlation (GONÇALVES et al., 2008; RÊGO et al., 2011; MOULIN et al., 2012).

The estimate of the relative contribution of each character in the expression of the genetic divergence, based on the Singh method (1981), indicated that the diameter of the fruit $(20.19 \%)$, followed by height of the plant $(19.46 \%)$, cup diameter, (14.91\%) and length of the fruit (14.57\%) were the characters that most contributed to the total divergence $(69.13 \%)$ among the 30 pepper accessions (Table 3 ).

Width and length of the leaf were the ones which least contributed, representing a percentage of $3.65 \%$ and $2.68 \%$ respectively. DOMENICO et al. (2012), working with nine accessions of $\boldsymbol{C}$. chinense, verified that length of the fruit $(24.2 \%)$ and productivity $(23.8 \%)$ were the characters that most contributed to the genetic divergence. SILVA NETO et al. (2014), when characterizing a population of . annuum, observed that diameter of the stem (68.97\%) and diameter of the cup $(9.22 \%)$ were the characteristics that contributed most.
Table 3 - Relative contribution of the agronomic characters for the genetic divergence among the 30 pepper accessions by the method proposed by SINGH (1981).

\begin{tabular}{lcc}
\hline Character & Value (\%) & $\begin{array}{l}\text { Cummulative } \\
\text { Value }(\%)\end{array}$ \\
\hline Diameter of the fruit & 20.19 & 20.19 \\
Plant height & 19.46 & 39.65 \\
Diameter of the cup & 14.91 & 54.56 \\
Length of the fruit & 14.57 & 69.13 \\
Number of locules & 10.82 & 79.95 \\
Width of the stem & 9.97 & 89.92 \\
Number of seeds & 3.75 & 93.67 \\
Width of the leaf & 3.65 & 97.32 \\
Length of the leaf & 2.68 & 100.00 \\
\hline
\end{tabular}

\section{CONCLUSION}

The morpho-agronomic characterization was efficient in estimating the genetic diversity of accessions, evidencing great divergence and being this an important tool for improvement, providing the best knowledge and use of the accessions. All the accessions were considered different which allowed disregarding a hypothesis of duplicates.

Correlation between the genetic distance and the origin of accessions was not observed, which can be a reflection of the common practice of exchanging peppers among rural producer.

\section{ACKOWLEDGEMENTS}

To Fundação de Apoio à Pesquisa e Estudo na Área de Saúde (FAPES), for the grant of aid and scholarship for the development of this research and to Instituto Federal do Espírito Santo (IFES) for the financial support destined to the article translation.

\section{REFERENCES}

ALBRECHT, E. et al. Genetic diversity and population structure of Capsicum baccatum genetic resources. Genetic Resources and Crop Evolution, v.59, n.7, p.517-538, 2012. Available from: $<$ http://link.springer.com/article/10.1007\%2Fs10722-011-9700y\#page-1>. Accessed: May 22, 2015.

BENTO, C.S. et al. Descritores qualitativos e multicategóricos na estimativa da variabilidade fenotípica entre acessos de pimentas. Scientia Agraria (UFPR), v.8, n.3, p.147-154, 2007. Available from: $\quad<$ http://ojs.c3sl.ufpr.br/ojs/index.php/agraria/article/ viewFile/8379/6661>. Accessed: Oct. 8, 2014.

CRUZ, C.D. Programa genes (versão Windows): aplicativo computacional em genética e estatística. Viçosa: UFV, 2008. Available from: <http://www.ufv.br/dbg/genes/genes.htm>. Accessed: May 24, 2015. 
DOMENICO, C.I. et al. Caracterização agronômica e pungência em pimenta de cheiro. Horticultura Brasileira, v.30, n.2, p.466-472, 2012. Available from: <http://www.scielo.br/scielo. php?pid=S0102-05362012000300018\&script $=$ sci_arttext $>$. Accessed: May 22, 2015.

FILGUEIRA, F.A.R. Novo manual de olericultura: agrotecnologia moderna na produção e comercialização de hortaliças. Viçosa: UFV, 2008. 412p.

FINGER, F.L. et al. Genetic diversity of Capsicum chinensis (Solanaceae) accessions based on molecular markers and morphological and agronomic traits. Genetics and Molecular Research, v.9, p.1852-1864, 2010. Available from: <http:// www.funpecrp.com.br/gmr/year2010/vo19-3/pdf/gmr891.pdf>. Accessed: Sept. 05, 2015.

FONSECA, R.M. et al. Morphologic characterization and genetic diversity of Capsicum chinense Jacq. accessions along the upper Rio Negro - Amazonas. Crop Breeding and Applied Biotechnology, v.8, p.187-194, 2008. Available from: <http:// www.sbmp.org.br/cbab/siscbab/uploads/c8129493-b909-2607. pdf $>$. Accessed: May 24, 2015.

GONÇALVES, L.S.A. et al. Divergência genética em tomate estimada por marcadores RAPD em comparação com descritores multicategóricos. Horticultura Brasileira, v.26, n.3, p.364370, 2008. Available from: <http://www.scielo.br/scielo. php?pid $=$ S0102-05362008000300014\&script $=$ sci_arttext $>$. Accessed: Oct. 8, 2014.

HILL, T.A. et al. Characterization of Capsicum annuum genetic diversity and population structure based on parallel polymorphism discovery with a $30 \mathrm{~K}$ unigene pepper genechip. Plos One, v.8, p.1-16, 2013. Available from: <http://journals.plos.org/plosone/ article?id=10.1371/journal.pone.0056200>. Accessed: May 24, 2015.

JARRET, R.L.; BERKE, T. Variation for fruit morphological characteristics in a Capsicum chinense Jacq. germplasm collection. HortScience, v.43, n.2, p.1694-1697, 2008. Available from: <http://hortsci.ashspublications.org/content/43/6/1694.full $>$. Accessed: May 22, 2015.

MOSCONE, E.A. et al. The evolution of the chili pepper (Capsicum - Solanaceae): a cytogenetic perspective. Acta Horticulture, v.745, n 4, p.137-169, 2007.
MOULIN, M.M. et al. Collection and morphological characterization of sweet potato landraces in north of Rio de Janeiro state. Horticultura Brasileira, v.30, n.2, p.4051, 2012. Available from: <http://www.scielo.br/scielo. php? pid $=$ S0102-05362012000200017\&script $=$ sci_arttext $>$. Accessed: Aug. 28, 2014.

NEITZKE, R.S. et al. Dissimilaridade genética entre acessos de pimenta com potencial ornamental. Horticultura Brasileira, v.28, n.4, p.47-53, 2010. Available from: <http://www.scielo.br/ scielo.php?script=sci arttext\&pid=S0102-05362010000100009>. Accessed: Oct. 8, $201 \overline{4}$.

RODRIGUES, R. et al. Combining ability and heterosis for agronomic traits in chili pepper. Horticultura Brasileira, v.30, n.2, p.226-233, 2012. Available from: <http://www.scielo.br/pdf/ hb/v30n2/v30n2a08.pdf>. Accessed: Oct. 8, 2014.

SCOTT, A.J; KNOTT, M.A. Cluster analysis methods for grouping means in the analysis of variance. Biometrics, v.30, p.507512, 1974. Available from: <http://www.ime.usp.br/ abe/lista/ pdfXz71qDkDx1.pdf>. Accessed: Oct. 8, 2014.

SILVA NETO, J.J. et al. Variabilidade em população base de pimenteiras ornamentais (Capsicum annuum L.). Revista Ceres, v.61, n.1, p.084-089, 2014. Available from: <http://www.scielo.br/ scielo.php?pid=S0034-737X2014000100011\&script $=$ sci_arttext $>$. Accessed: Jan. 18, 2015.

SINGH, D. The relative importance of characters affecting genetic divergence. Indian Journal of Genetic and Plant Breeding, v.41, p.237-245, 1981.

SUDRÉ, C.P. et al. Divergência genética entre acessos de pimenta e pimentão utilizando técnicas multivariadas. Horticultura Brasileira, v.23, n.1, p.22-27, 2005. Available from: $<$ http://www. scielo.br/pdf/hb/v23n1/a05v23n1>. Accessed: May 22, 2015.

RAO, R.C. Advanced statistical methods in biometric research. New York: J, 1952. 330p.

RÊGO, E.R. et al. Morphological and chemical characterization of fruits of Capsicum spp. accessions. Horticultura Brasileira, v.29, n.2, p.364-371, 2011. Available from: <http://www.scielo.br/ scielo.php?pid=S0102-05362011000300018\&script=sci_arttext $>$. Accessed: May 02, 2015. 